\title{
BUDIDAYA UDANG VANAME (Litopenaeus vannamei) TEKNOLOGI INTENSIF MENGGUNAKAN BENIH TOKOLAN
}

\author{
Markus Mangampa dan Hidayat Suryanto Suwoyo \\ Balai Riset Perikanan Budidaya Air Payau \\ Jl. Makmur Dg Sitakka 129 Maros, Sulawesi Selatan 90512 \\ E-mail:mmangampa@yahoo.com
}

(Naskah diterima: 3 April 2010; Disetujui publikasi: 18 November 2010)

\begin{abstract}
ABSTRAK
Salah satu jenis udang yang cukup potensial untuk dikembangkan adalah udang vaname (Litopenaeus vannamei). Budidaya ini berkembang dengan teknologi intensif, namun terbatas pada golongan masyarakat menengah ke atas (padat modal). Riset ini bertujuan untuk mendapatkan data dan informasi pengaruh penggunaan tokolan terhadap produksi, Rasio Konversi Pakan (RKP) pada pembesaran udang vaname teknologi intensif. Riset ini dilaksanakan di tambak Punaga, Takalar, Instalasi Balai Riset Perikanan Budidaya Air Payau (BRPBAP), menggunakan empat petak masing masing berukuran $4.000 \mathrm{~m}^{2} /$ petak. Hewan uji adalah udang vaname dengan perlakuan: (A) pembesaran dengan tebar benur (PL-12), dan (B) pembesaran dengan tebar tokolan (PL-27). Setiap perlakuan dengan 2 ulangan, kepadatan benur dan tokolan adalah 50 ekor $/ \mathrm{m}^{2}$, dan pemeliharaan berlangsung 80 hari di tambak. Hasil yang diperoleh pada perlakuan B memperlihatkan pertumbuhan mutlak (11,114 $\pm 0,258 \mathrm{~g} /$ ekor), sintasan $(92,55 \pm 0,23 \%)$, produksi $(2.087,5 \pm 88,2 \mathrm{~kg} /$ petak) lebih tinggi daripada perlakuan $\mathrm{A}$ yaitu: pertumbuhan mutlak $(10,085 \pm 0,120 \mathrm{~g}$ /ekor), sintasan $(90,83 \pm 8,51 \%)$, produksi $(1.831,0 \pm 149,9 \mathrm{~kg} /$ petak), namun ketiga peubah ini berbeda tidak nyata antara kedua perlakuan. RKP lebih rendah pada perlakuan B $(1,096 \pm 0,034)$ berbeda nyata dengan perlakuan A $(1,257 \pm 0,048)$. Peubah kualitas air memperlihatkan sebaran kisaran yang merata untuk kedua perlakuan, kecuali nitrit $\left(\mathrm{NO}_{2}\right)$ memperlihatkan kisaran yang tinggi pada perlakuan $B(0,18235 \mathrm{mg} / \mathrm{L})$ dibandingkan dengan perlakuan $A(0,0328 \mathrm{mg} / \mathrm{L})$ pada akhir penelitian. Hal ini disebabkan waktu panen yang berbeda sesuai dengan kondisi musim yaitu kualitas air sumber semakin menurun. Kualitas air sumber yang menurun ini diikuti oleh meningkatnya total vibrio di air laut mencapai; $4,3310^{4} \mathrm{cfu} / \mathrm{mL}$ dibandingkan dalam air tambak $829.10^{2} \mathrm{cfu} / \mathrm{mL}$. Kesimpulan memperlihatkan bahwa penggunaan tokolan (PL-27) menghasilkan produksi yang tinggi dan rasio konversi pakan yang rendah.
\end{abstract}

KATA KUNCI: udang vaname, benur, tokolan, teknologi intensif

ABSTRACT: Vannamei shrimp (Litopenaeus vannamei) intensive culture technology using shrimp. By: Markus Mangampa and Hidayat Suryanto Suwoyo

One species of shrimps that has the potential to be developed for aquaculture is whiteleg shrimp (Litopenaeus vannamei). The recent cultivation method has been developed using intensive technology, but can only be afforded by middle and upper social groups (capital intensive). This research was aimed to study the influence of using shrimp juvenile on the production and feed conversion ratio of whiteleg shrimp cultured in intensive system. The research was conducted at the research installation of the Research Institute for Coastal Aquaculture in Punaga, Takalar Regency. Four 


\begin{abstract}
ponds each sized of $4,000 \mathrm{~m}^{2}$ were used in this research. The treatment was applied i.e grow-out of post-larvae 12 (PL-12) (A) and grow-out of shrimp juvenile (PL-27) (B) each with stocking density of 50 ind. $/ \mathrm{m}^{2}$. Each treatment was arranged in two replications and reared for 80 days. The results obtained in treatment $B$ showed that absolute growth (11.114 $0.258 \mathrm{~g} / \mathrm{ind}$.), survival $(92,55 \pm 0,23 \%)$, and production $(2,087.5 \pm 88.2 \mathrm{~kg} /$ pond) was higher than those of in treatment $A$ (absolute growth, $10.085 \pm 0.120 \mathrm{~g} /$ ind., survival rate, $90.83 \pm 8.51 \%$, production, $1,831.0 \pm 149.9 \mathrm{~kg} /$ pond), but all parameters were not significantly different between both treatments. Feed conversion ratio $(F C R)$ was lower in treatment $B(1.096 \pm 0034)$ and significantly different with treatment $A(1.257 \pm 0.048)$. Water quality parameters showed similar variations in both treatments, except Nitrite $\left(\mathrm{NO}_{2}\right)$ where a high range of Nitrite variation was recorded in treatment $B(0.18235 \mathrm{mg} / \mathrm{L})$ compared to treatment $A$ $(0.0328 \mathrm{mg} / \mathrm{L})$ at the end of research. This was due to different harvest times in accordance with the conditions of the season where at a particular time, the quality of water source was decreasing. The decrease of water quality was followed by the increase of total vibrio in seawater reaching $43310^{4} \mathrm{CFU} / \mathrm{mL}$ than in the pond water $829.10^{2} \mathrm{CFU} / \mathrm{mL}$. The conclusion is that using the shrimp juvenile, PL-27, high shrimp production and low RKP can be achieved.
\end{abstract}

\title{
KEYWORDS: vannamei shrimp, fries, juvenile, intensive culture system, production
}

\section{PENDAHULUAN}

Budidaya udang vaname (Litopenaeus vannamei) berkembang pesat dengan teknologi intensif oleh karena ketersediaan benih SPF (Spesific Pathogen Free), sehingga dapat ditebar dengan kepadatan yang lebih tinggi, dan memiliki sintasan serta produksi yang tinggi (Anonim, 2003; Poernomo, 2004). Di Indonesia kepadatan yang umum dilakukan di berbagai daerah berkisar $80-100$ ind. $/ \mathrm{m}^{2}$ udang vaname dan dapat ditingkatkan hingga 244 ind./ $\mathrm{m}^{2}$, dengan menggunakan probiotik yang mampu menghasilkan produksi 37,5 ton/ ha/siklus (Poernomo, 2004). Namun produksi yang tinggi tidak selamanya diikuti oleh keuntungan yang tinggi. Di samping itu, penerapan kepadatan tinggi terbatas pada golongan masyarakat menengah ke atas. Produksi yang tinggi akan berdampak kepada beban limbah yang dihasilkan baik oleh sisa pakan apabila rasio konversi pakan tinggi, maupun kotoran udang.

Setelah penurunan produksi pada budidaya udang windu, maka dikembangkan suatu teknologi yang dapat memperbaiki teknologi budidayanya yaitu teknologi pentokolan (teknologi pembantutan), walaupun terbatas pada tingkatan teknologi tradisional plus dan semi-intensif. Keunggulan teknologi ini pada budidaya udang windu adalah efisiensi penggunaan pakan. Pada udang windu menggunakan tokolan 45 hari dari PL-12 pada pembesaran udang pola semi intensif dapat memberikan manfaat antara lain: meningkatkan vitalitas tokolan udang dan memperpendek masa pemeliharaan di pembesaran yaitu 85 90 hari untuk mencapai bobot rata-rata 25-27 g/ekor, meningkatkan produksi dan sintasan di pembesaran mencapai 70\%-89\%, dan mengefisienkan penggunaan pakan dengan rasio koversi pakan (RKP) 1,08-1,30. Di samping itu, menjamin ketersedian benih tokolan dengan kesesuian pola tanam di pembesaran (Mustafa \& Mangampa, 1990; Mangampa \& Mustafa, 1992). Bertitik tolak dari hal ini maka dilakukan penelitian penggunaan tokolan pada budidaya udang vaname, dan dilaporkan sebelumnya bahwa umur tokolan yang terbaik adalah 15 hari dari PL-12 yang dilakukan dalam skala laboratorium (Tahe et al., 2009). Pengunaan tokolan 15 hari juga dapat meningkatkan produksi pada pembesaran udang vaname tradisional plus di tambak dan menghasilkan RKP yang rendah, sehingga memberikan efisiensi biaya dalam biaya operasional (Mangampa et al., 2009). Di samping itu, pemeliharaan disarankan hanya berlangsung 75 hari pada pembesaran udang vaname tradisional plus.

Sehubungan dengan hal tersebut maka dilakukan penelitian yang memungkinkan dapat menekan biaya operasional pada budidaya udang vaname intensif yaitu dengan menggunakan tokolan. Penelitian ini bertujuan untuk mendapatkan data dan informasi pengaruh penggunaan tokolan terhadap pertumbuhan, sintasan, produksi, dan RKP 
yang dapat menghasilkan efisiensi dalam biaya produksi budidaya udang vaname intensif.

\section{BAHAN DAN METODE}

Penelitian dilakukan di tambak Instalasi Penelitian Punaga, Balai Riset Perikanan Budidaya Air Payau dengan menggunakan empat petak tambak pembesaran berukuran $4.000 \mathrm{~m}^{2} /$ petak. Hewan uji adalah udang vaname berupa benur vaname (PL-12) dan tokolan (PL-27) dengan perlakuan: $\mathrm{A}=\mathrm{Pem}-$ besaran dengan penebaran benur (PL-12); dan $\mathrm{B}=$ Pembesaran menggunakan tokolan 15 hari (PL-27), masing-masing perlakuan dengan dua ulangan. Benur vaname yang ditebar adalah benur SPF atau bebas WSSV dan TSV (pengamatan PCR). Baik perlakuan A maupun perlakuan $B$ ditebar dengan kepadatan yang sama yaitu $A=50$ ekor $/ \mathrm{m}^{2}$ benur PL-12 dan $B=$ 50 ekor $/ \mathrm{m}^{2}$ tokolan dengan benur dari induk yang sama. Untuk mendapatkan tokolan udang vaname maka dilakukan kegiatan pentokolan selama 15 hari menggunakan hapa berukuran $2 \mathrm{~m} \times 3 \mathrm{~m} \times 1 \mathrm{~m}$ dengan kepadatan 6.000 ekor/ $\mathrm{m}^{3}$ (Mangampa \& Hendrajat, 2008). Kegiatan ini bukan merupakan perlakuan, tetapi hanya dilakukan untuk mendapatkan tokolan vaname yang berkualitas.

Kegiatan penelitian dimulai dengan persiapan tambak sesuai dengan protap persiapan budidaya udang yaitu: pengeringan/pengolahan tanah dasar dengan sempurna (ditandai dengan potensial redoks yang bernilai + ), pemberantasan hama dan pengapuran. Persiapan air untuk penebaran diupayakan dengan penumbuhan plankton sehingga perlu dilakukan pemupukan dasar dengan pupuk organik (butiran) dan anorganik (Urea + TSP). Pemeliharaan air ini berlangsung selama 3 minggu dan aplikasi probiotik 1 minggu sebelum penebaran. Kultur bakteri menggunakan probiotik dengan dosis rata-rata 3,5-5,5 L/ha setiap minggu dan dikultur melalui proses fermentasi selama 3 hari. Media kultur adalah tepung ikan, dedak halus, yeast, molase, garam, dan air tawar yang sudah masak dengan dosis sesuai dengan pedoman yang sudah ada. Pemberian pakan komersial dimulai pada saat penebaran dengan dosis dan frekuensi adalah 2\%-100\% untuk perlakuan A dan $2 \%-20 \%$ untuk perlakuan B dengan frekuensi 3-5 kali/hari.

Peubah kualitas air yang diamati meliputi: $\mathrm{pH}$, suhu, oksigen terlarut, salinitas yang dilakukan setiap hari, sedangkan BOT, $\mathrm{NO}_{2}$, $\mathrm{NO}_{3} \mathrm{NH}_{4}$, dan $\mathrm{PO}_{4}$, kepadatan/jenis plankton, populasi bakteri, dan vibrio dilakukan setiap 2 minggu. Laju pertumbuhan diamati setiap 2 minggu, sedangkan pertumbuhan mutlak, sintasan, dan RKP dihitung pada akhir penelitian dan dianalisis dengan Uji T.

\section{HASIL DAN BAHASAN}

\section{Pertumbuhan, Sintasan, Produksi, dan RKP}

Hasil yang diperoleh selama 80 hari pemeliharaan di tambak, memperlihatkan pertumbuhan mutlak, sintasan, produksi, dan RKP yang bervariasi pada kedua perlakuan (Tabel 1).

Selama 80 hari pemeliharaan di tambak memperlihatkan pertumbuhan mutlak yang tinggi pada perlakuan pembesaran dengan penebaran tokolan 15 hari (PL-27) yaitu $11,114 \pm 0,258 \mathrm{~g} /$ ekor, dibandingkan dengan pembesaran dengan tebar benur (PL-12) yaitu $10,085 \pm 0,120 \mathrm{~g} /$ ekor, namun berbeda tidak nyata antara kedua perlakuan ini. Bobot akhir rata-rata kedua perlakuan memperlihatkan bahwa dengan menggunakan tokolan 15 hari (B) bobot rata-rata setelah 70 hari di pembesaran relatif sama dengan bobot rata-rata perlakuan A tebar benur (PL-12) setelah 80 hari di pembesaran (Gambar 1). Hal ini disebabkan tokolan sudah merupakan benur seleksi alami di tambak sehingga mempunyai vitalitas yang lebih baik dibandingkan dengan benur langsung dari hatcheri.

Sintasan dan produksi pada kedua perlakuan tidak memperlihatkan perbedaan yang nyata, walapun sintasan dan produksi lebih tinggi pada pembesaran menggunakan tokolan (B) yaitu masing-masing: 92,55 $\pm 0,23 \%$ dan $2.087,5 \pm 88,2 \mathrm{~kg} /$ petak, dibandingkan pembesaran menggunakan benur $(A)$ dengan sintasan dan produksi masing-masing $90,83 \pm 8,51 \%$ dan $1.831,0 \pm 149,9 \mathrm{~kg} / \mathrm{ha}$. Dilihat dari standar deviasi kedua peubah ini memperlihatkan variasi yang cukup besar pada kedua ulangan dari perlakuan pembesaran menggunakan benur (A).

Dari uji T, peubah yang dihitung pada akhir penelitian hanya rasio konversi pakan (RKP) yang memperlihatkan perbedaan yang nyata antara kedua perlakuan yaitu RKP rendah pada pembesaran menggunakan tokolan yaitu 
Tabel 1. Pertumbuhan, sintasan, produksi, dan rasio konversi pakan udang vaname selama 80 hari pemeliharaan

Table 1. Growth rate, survival rate, production, and FCR of Litopenaeus vannamei after 80 days culture period

\begin{tabular}{|c|c|c|}
\hline \multirow{2}{*}{$\begin{array}{l}\text { Paramet er variabel } \\
\text { Variable parameters }\end{array}$} & \multicolumn{2}{|c|}{ Perlakuan (Treatments) } \\
\hline & $\begin{array}{l}\text { (A) Tebar benur (PL-12) } \\
\text { (A) Fries stocking (PL-12) }\end{array}$ & $\begin{array}{l}\text { (B) Tebar tokolan (PL-27) } \\
\text { (B) Juvenile stocking (PL-27) }\end{array}$ \\
\hline $\begin{array}{l}\text { Luas petakan ( } \mathrm{m}^{2} / \text { petak) } \\
\text { Pond square }\left(\mathrm{m}^{2} / \text { pond }\right)\end{array}$ & 4,000 & 4,000 \\
\hline $\begin{array}{l}\text { Padat te bar (ekor/petak) } \\
\text { Stocking densities (ind./pond) }\end{array}$ & 200,000 & 200,000 \\
\hline $\begin{array}{l}\text { Bobot awal rata-rata (g/ekor) } \\
\text { Initial weight (g/ind.) }\end{array}$ & 0.004 & 0.164 \\
\hline $\begin{array}{l}\text { Bobot akhir rata-rata (g/e kor) } \\
\text { Final weight (g/ind.) }\end{array}$ & $10.089 \pm 0.120^{\mathrm{a}}$ & $11.278 \pm 0.258^{\mathrm{a}}$ \\
\hline $\begin{array}{l}\text { Pertumbuhan mutlak (g/ekor) } \\
\text { Growth absolute (g/ind.) }\end{array}$ & $10.085 \pm 0.120^{\mathrm{a}}$ & $11.114 \pm 0.258^{\mathrm{a}}$ \\
\hline $\begin{array}{l}\text { Sintasan (\%) } \\
\text { Survival rate (\%) }\end{array}$ & $90.83 \pm 8.51^{\mathrm{a}}$ & $92.55 \pm 0.23^{a}$ \\
\hline $\begin{array}{l}\text { Produksi (kg/petak) } \\
\text { Production (kg/pond) }\end{array}$ & $1,831.0 \pm 149.9^{a}$ & $2,087.5 \pm 88.2^{\mathrm{a}}$ \\
\hline $\begin{array}{l}\text { Rasio Konversi Pakan (RKP) } \\
\text { Feed Convertion Ratio (FCR) }\end{array}$ & $1.257 \pm 0.048^{\mathrm{a}}$ & $1.096 \pm 0.034^{b}$ \\
\hline
\end{tabular}

") Angka rata-rata pada kolom atau baris yang diikuti huruf superscript yang sama tidak menunjukkan perbedaan yang nyata $(P>0,05)$

Average values in a column or row with the same superscript letter indicate no significant difference $(P>0.05)$

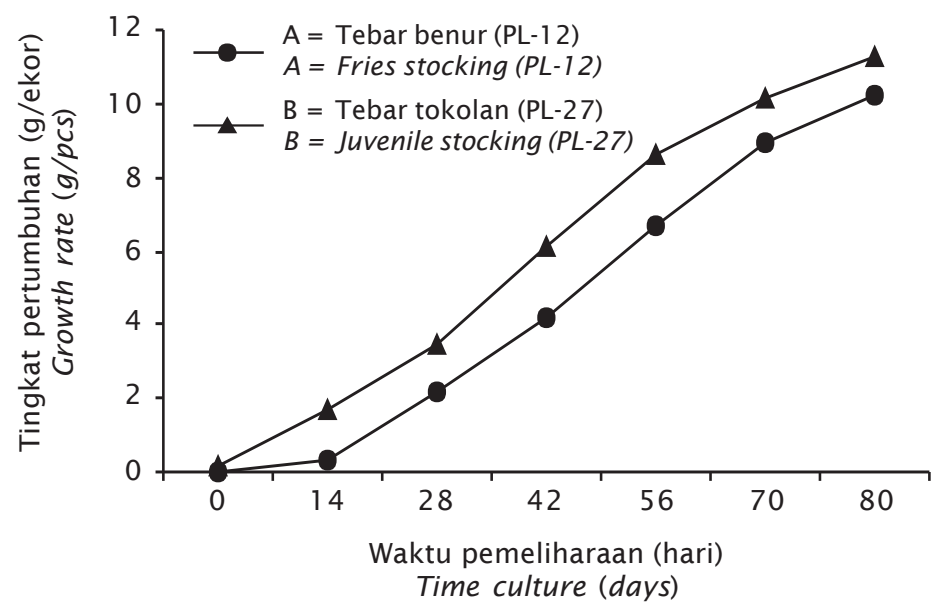

Gambar 1. Pertumbuhan udang vaname pada pembesaran selama 80 hari pemeliharaan

Figure 1. Growth rate of Litopenaeus vannamei during 80 days of culture period in the brackhiswater ponds 
$1,096 \pm 0.034$, berbeda nyata dengan RKP pembesaran menggunakan benur yaitu $1,257 \pm 0,048$. Perbedaan RKP ini sangat menentukan efisiensi dalam biaya operasional yaitu pakan, di mana kita ketahui bahwa biaya operasional yang terbesar pada budidaya udang vaname intensif adalah pakan yang dapat mencapai $60 \%$. Hal ini sesuai prinsip pentokolan pada udang windu yaitu dengan menebar tokolan (benih yang dibantut) memberikan manfaat efisiensi penggunaan pakan (Mustafa \& Mangampa, 1990; Mangampa \& Mustafa, 1992).

\section{Kualitas Air}

Peubah kualitas air: suhu, oksigen terlarut, $\mathrm{pH}$, salinitas, BOT, $\mathrm{PO}_{4}, \mathrm{NO}_{3}$, dan $\mathrm{NH}_{3}$, memperlihatkan kisaran dengan pola sebaran yang relatif sama antara kedua perlakuan (Tabel 2 ). Kecuali peubah kualitas air $\mathrm{NO}_{2}$ memperlihatkan sebaran yang bervariasi antara kedua perlakuan.

Bahan organik total menggambarkan kandungan bahan organik total suatu perairan yang terdiri atas bahan organik terlarut, tersuspensi, dan koloid. Hasil pengamatan kandungan bahan organik total (BOT) yang didapatkan pada perlakuan A (tebar benur) berkisar 28,61-52,67 dan perlakuan B (tebar tokolan) berkisar 19,36-50,81 mg/L (Gambar 2).
Kisaran ini tergolong layak dalam proses budidaya udang vaname sesuai yang dikemukakan Adiwijaya et al. (2003) bahwa kisaran optimal bahan organik total pada budidaya udang vaname $<55 \mathrm{mg} / \mathrm{L}$. Kondisi yang layak ini diduga disebabkan oleh ketersediaan oksigen terlarut yang cukup dan pemberian probiotik yang bertujuan untuk membantu aktivitas bakteri dalam penguraian bahan organik menjadi senyawa sederhana. Menurut Boyd (1982), kandungan BOT suatu perairan normal adalah maksimum $15 \mathrm{mg} / \mathrm{L}$, kandungan BOT tinggi maka dapat menurunkan kandungan oksigen terlarut dalam air sehingga menurunkan daya tahan udang.

Fosfat selama penelitian relatif sama antara kedua perlakuan yaitu: 0,0126-0,5163 $\mathrm{mg} / \mathrm{L}$ (perlakuan A) dan 0,0251-0,5146 mg/L (perlakuan B). Demikian pula pola penyebaran hampir sama dari awal sampai akhir pemeliharaan (Gambar 3).

Keberadaan unsur hara yang relatif sama antara kedua perlakuan dikarenakan dosis dan frekuensi yang sama dalam pemupukan dasar dan susulan menggunakan pupuk TSP dan organik.

Konsentrasi fosfat selama penelitian tergolong tingkat kesuburan sedang berdasarkan kriteria Joshimura (1983) dalam Effendie (2000), perairan dengan tingkat

Tabel 2. Kisaran kualitas air selama 80 hari pemeliharaan di tambak

Table 2. Ranges of water quality parameter during 80 days of culture period in the brackhiswater pond

\begin{tabular}{|c|c|c|}
\hline \multirow{2}{*}{$\begin{array}{c}\text { Parameter kualitas air } \\
\text { Water quality parameters }\end{array}$} & \multicolumn{2}{|c|}{$\begin{array}{l}\text { Kisaran kualitas air } \\
\text { Range water quality }\end{array}$} \\
\hline & $\begin{array}{l}\text { Tebar benur (PL-12) } \\
\text { Fries stocking (PL-12) }\end{array}$ & $\begin{array}{l}\text { Tebar tokolan (PL-27) } \\
\text { Juvenile stocking (PL-27) }\end{array}$ \\
\hline Suhu (Temperature) $\left({ }^{\circ} \mathrm{C}\right)$ & $28.9-31$ & $29.2-30.9$ \\
\hline $\begin{array}{l}\text { Oksigen terlarut } \\
\text { Disolved oxygen (mg/L) }\end{array}$ & $2.25-4.45$ & $2.0-5.65$ \\
\hline $\mathrm{pH}$ & 7.4-8.4 & $7.6-8.3$ \\
\hline Kadar garam (Salinity) (ppt) & $28.5-44.0$ & $29-42$ \\
\hline BOT (Total Organic Matter) (mg/L) & $28.61-52.67$ & $19.36-50.81$ \\
\hline Fosfat $\left(\mathrm{PO}_{4}\right)(\mathrm{mg} / \mathrm{L})$ & $0.0126-0.5163$ & $0.0251-0.5146$ \\
\hline Nitrat $\left(\mathrm{NO}_{3}\right)(\mathrm{mg} / \mathrm{L})$ & $0.0161-0.0937$ & $0.0082-0.1806$ \\
\hline Amonia $\left(\mathrm{NH}_{3}\right)(\mathrm{mg} / \mathrm{L})$ & $0.0061-1.3756$ & $0.0133-0.8858$ \\
\hline Nitrit $\left(\mathrm{NO}_{2}\right)(\mathrm{mg} / \mathrm{L})$ & $0.0008-0.0538$ & $0.0008-0.3441$ \\
\hline
\end{tabular}




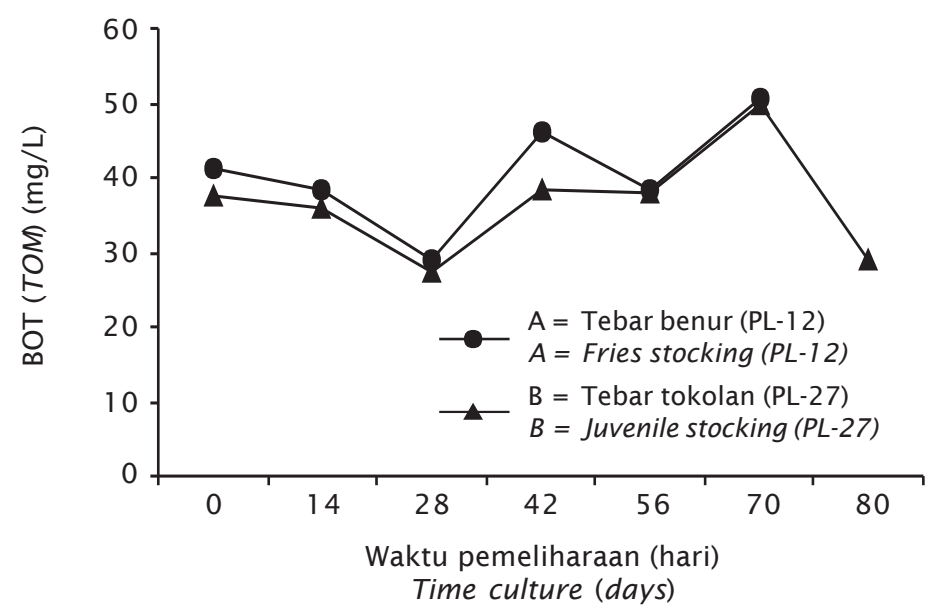

Gambar 2. Konsentrasi BOT (mg/L) selama 80 hari pemeliharaan

Figure 2. Concentration of Total Organic Matter $(\mathrm{mg} / \mathrm{L})$ during 80 days of culture period

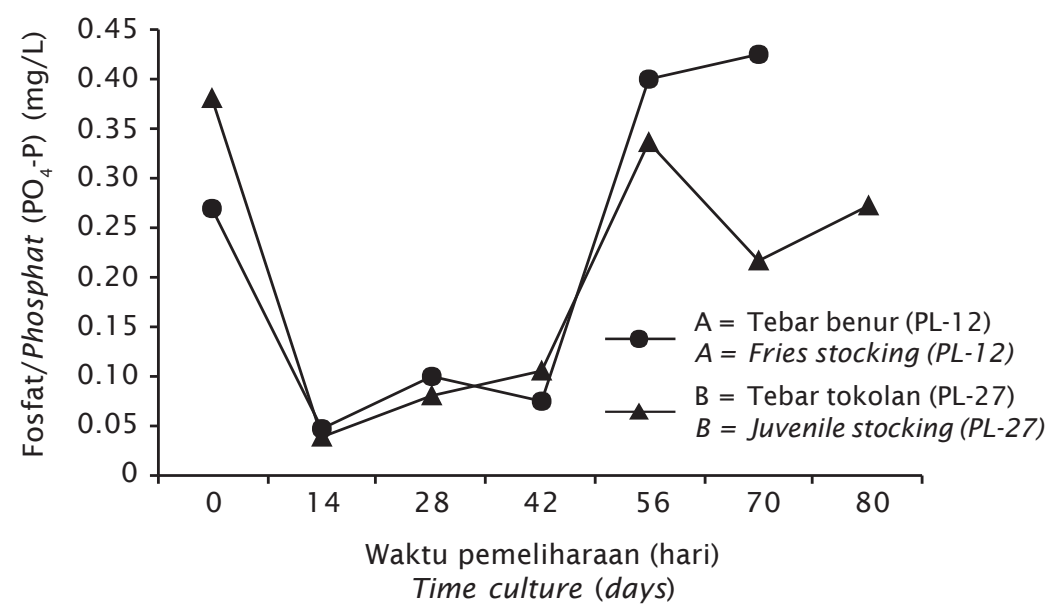

Gambar 3. Konsentrasi fosfat $\left(\mathrm{PO}_{4}\right)$ selama 80 hari pemeliharaan

Figure 3. Concentration of $\mathrm{PO}_{4}(\mathrm{mg} / \mathrm{L})$ during 80 days of culture period

kesuburan rendah kadar fosfatnya berkisar 0-0,02 $\mathrm{mg} / \mathrm{L}$; tingkat kesuburan sedang berkisar 0,021-0,05 mg/L; dan kesuburan tinggi berkisar 0,051-0,1 mg/L.

Nitrat adalah bentuk nitrogen utama dalam perairan alami dan sangat diperlukan oleh pertumbuhan akuatik (alga), sangat mudah larut dalam air bersifat stabil (Effendie, 2000). Pola penyebaran $\mathrm{NO}_{3}$ dalam perairan kedua perlakuan relatif sama dengan konsentrasi $\mathrm{NO}_{3}$ masing-masing 0,0161-0,0937 mg/L (perlakuan
A) dan perlakuan (B) 0,0082-0,1806 mg/L. (Gambar 4). Konsentrasi $\mathrm{NO}_{3}$ ini cukup layak dan diperlukan karena merupakan bentuk nitrogen yang dapat dimanfaatkan oleh plankton dalam pertumbuhannya. Menurut Clifford (1994), bahwa konsentrasi $\mathrm{NO}_{3}$ yang optimum untuk udang vaname berkisar 0,4-0,8 $\mathrm{mg} / \mathrm{L}$.

Kisaran amoniak cukup tinggi pada awal penebaran pada kedua perlakuan utamanya pada perlakuan A mencapai 1,3756 mg/L; 


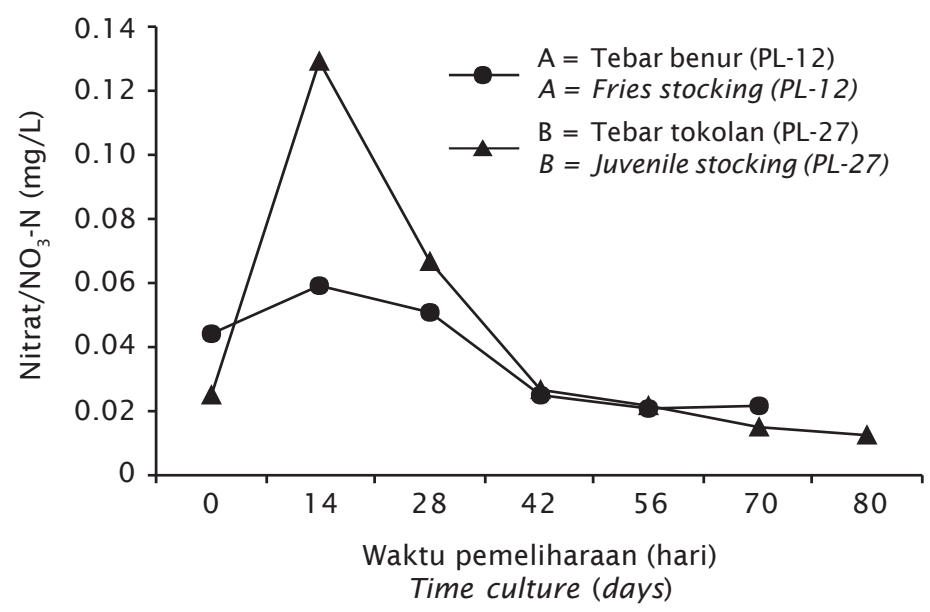

Gambar 4. Konsentrasi nitrat $\left(\mathrm{NO}_{3}\right)$ selama 80 hari pemeliharaan

Figure 4. Concentration of $\mathrm{NO}_{3}(\mathrm{mg} / \mathrm{L})$ during 80 days of culture period

sedangkan perlakuan B mencapai 0,8858 $\mathrm{mg} / \mathrm{L}$. Namun kisaran ini menurun setelah 2 minggu pemeliharaan baik untuk perlakuan $A$ maupun perlakuan B (Gambar 5). Pengamatan yang tinggi didapatkan sebelum penebaran benur dan tidak berlangsung lama.

Konsentrasi amoniak yang baku untuk budidaya udang vaname $<0,1 \mathrm{mg} / \mathrm{L}$ (Anonim, 2003). Boyd \& Fast (1992) mengatakan bahwa konsentrasi $\mathrm{NH}_{3}$ lebih dari 1,0 mg/L dapat menyebabkan kematian udang, sedangkan konsentrasi lebih dari 0,1 mg/L berpengaruh negatif terhadap pertumbuhan udang.

Hasil pengamatan nitrit dalam air tambak pada kedua perlakuan memperlihatkan pola penyebaran yang hampir sama dari awal sampai akhir pemeliharan perlakuan A 0,0008-0,0538; namun meningkat pada akhir pemeliharaan perlakuan B yang mencapai 0.0008-0,3441 $\mathrm{mg} / \mathrm{L}$ (Gambar. 6). Konsentrasi nitrit pada akhir pemeliharaan perlakuan B cukup tinggi sesuai pendapat Adiwijaya et al. (2003) bahwa kisaran

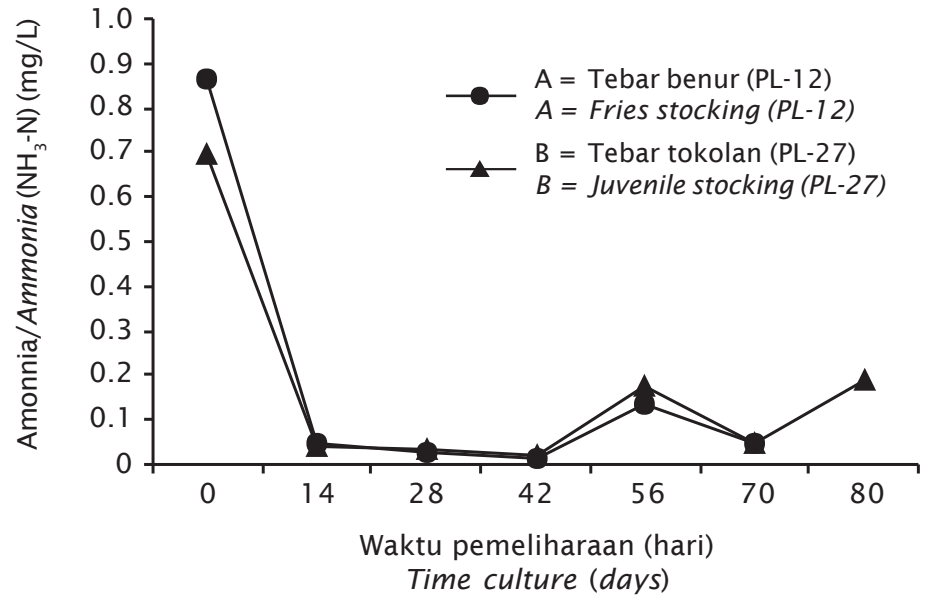

Gambar 5. Konsentrasi amoniak selama 80 hari pemeliharaan

Figure 5. Concentration of $\mathrm{NH}_{3}(\mathrm{mg} / \mathrm{L})$ during 80 days culture period 


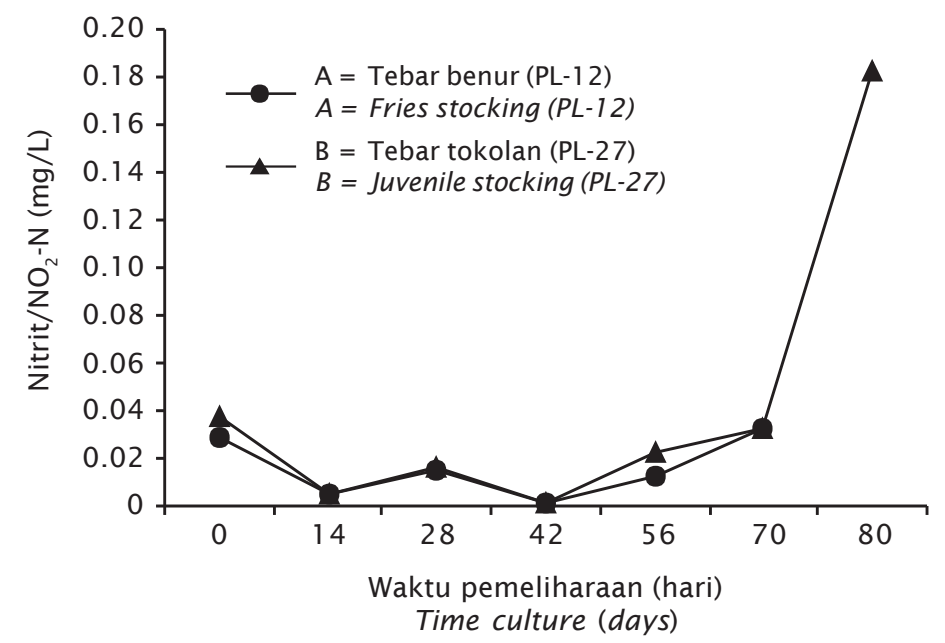

Gambar 6. Konsentrasi nitrit $\left(\mathrm{NO}_{2}\right)$ selama 80 hari pemeliharaan

Figure 6. Concentration of $\mathrm{NO}_{2}(\mathrm{mg} / \mathrm{L})$ during 80 days of culture period

optimum nitrit untuk budidaya udang vaname yakni 0,01-0,05 mg/L. Namun menurut Suprapto (2005), kandungan $\mathrm{NO}_{2}$ yang dapat ditoleransi oleh udang vaname berkisar 0,1 $1,0 \mathrm{mg} / \mathrm{L}$.

Pada awal pemeliharaan, kepadatan fitoplankton maupun zooplankton cukup padat dan pola penyebarannya merata pada kedua perlakuan. Hal ini disebabkan oleh pemupukan tanah dasar dengan jenis dan dosis pupuk yang sama. Fitoplankton didominasi oleh Guinardia sp., menyusul Pleurosigma sp., Chaetoceros sp., Oscillatoria sp., Protoperidinium sp., dan Navicula sp. Kelimpahan yang tinggi pada awal pemeliharaan sangat mendukung pertumbuhan benur vaname (Gambar 7).

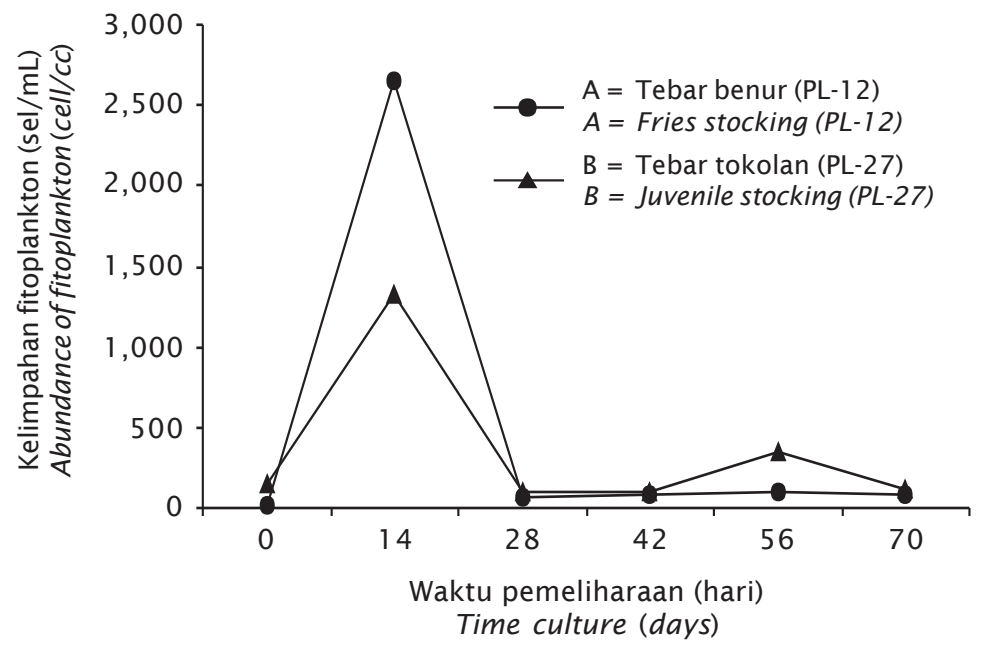

Gambar 7. Kelimpahan fitoplankton (sel/mL) selama 80 hari pemeliharaan

Figure 7. Abundance of phitoplankton (cel/cc) during 80 days of culture period 
Pakan alami dari zooplankton didominasi oleh jenis Branchionus sp., menyusul Nauplii Copepoda, Tortanus sp., dan Acartia sp., sedangkan Oithonia sp., Nitocra sp., dan Microsetella sp. dijumpai dalam kelimpahan yang rendah (Gambar 8).
Total bakteri dalam air tambak kedua perlakuan memperlihatkan populasi yang relatif stabil selama pemeliharaan, demikian pula total bakteri di dalam air tandon maupun air laut. Total bakteri selama pemeliharaan dalam perlakuan A 3-7,0607 cfu/mL dan

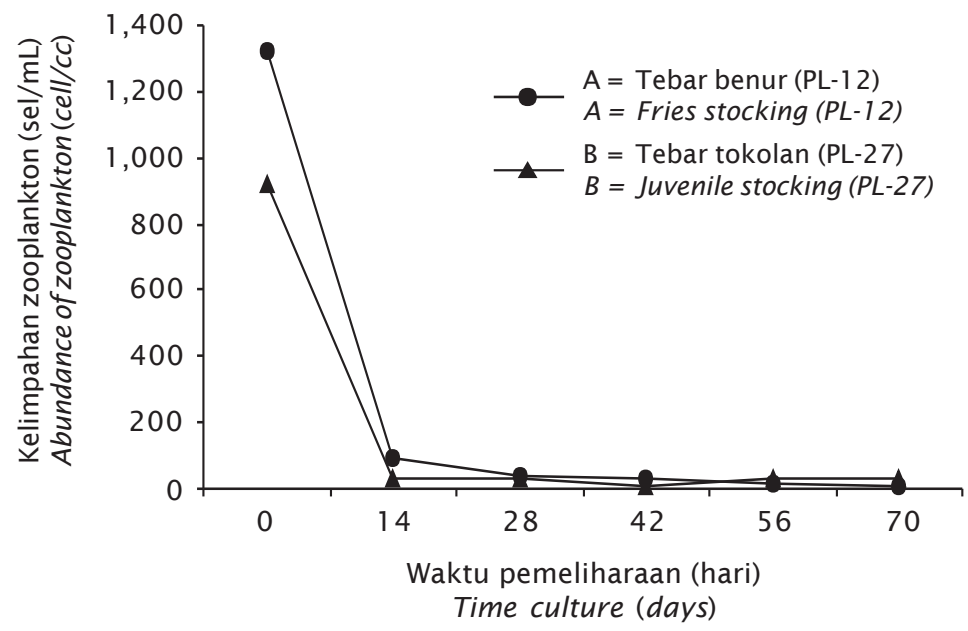

Gambar 8. Kelimpahan zooplankton (sel/mL) selama 80 hari pemeliharaan

Figure 8. Abundance of zooplankton (cel/cc) during 80 days of culture period

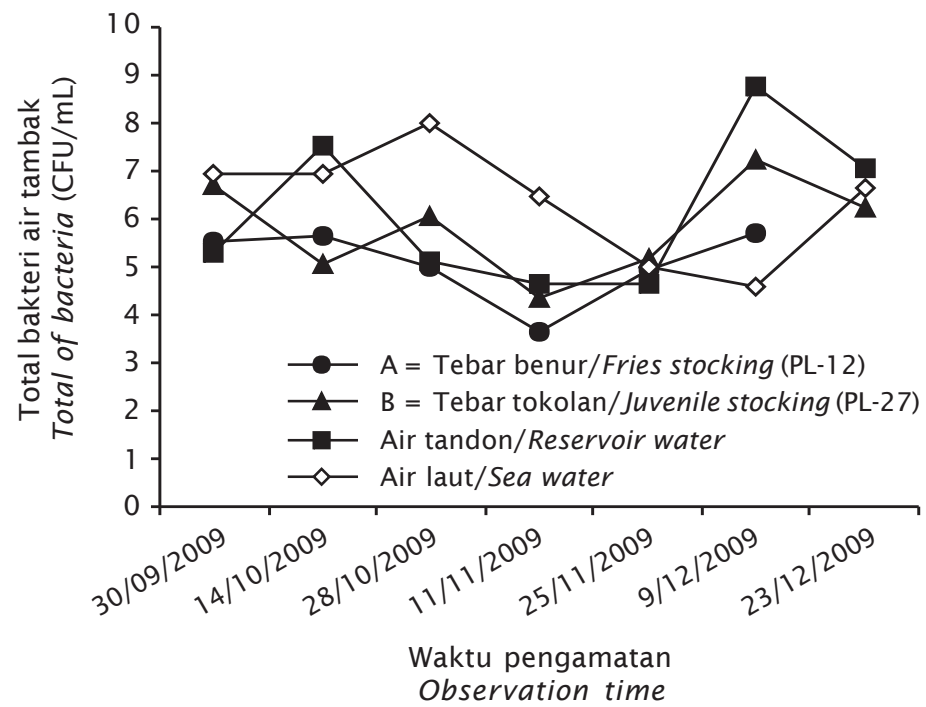

Gambar 9. Total bakteri (cfu/mL) dalam air tambak, tandon dan laut selama penelitian

Figure 9. Total of bacteria $(\mathrm{cfu} / \mathrm{mL})$ in the water pond, reservoir, and sea water during the experiment 


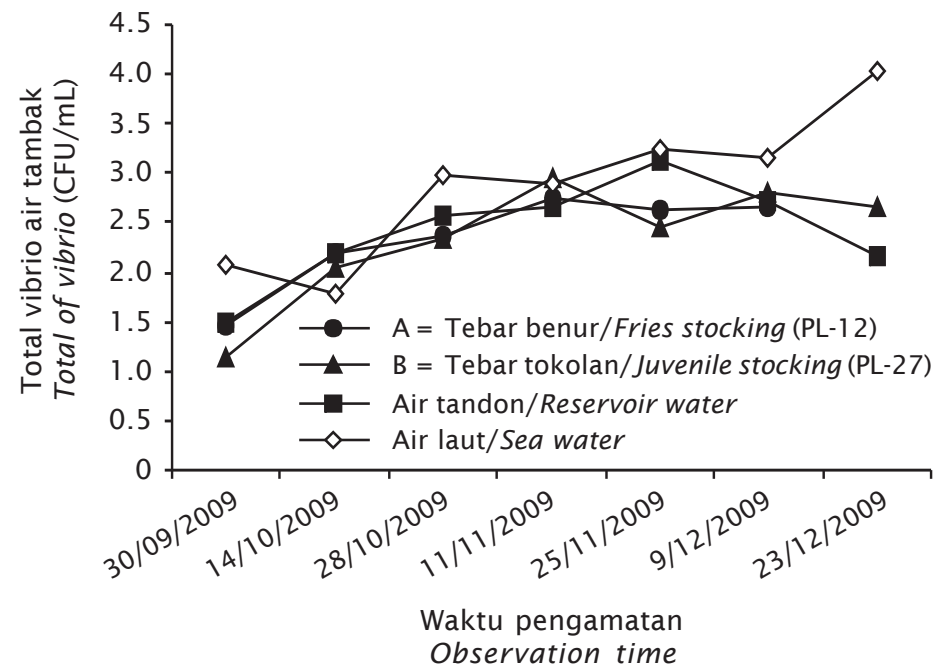

Gambar 10. Total vibrio dalam air tambak, tandon, dan laut selama penelitian

Figure 10. Total of vibrio $(\mathrm{cfu} / \mathrm{mL})$ in the water pond, reservoir, and sea water during the experiment

perlakuan B 4,3222-6,4698 cfu/mL; sedangkan dalam air tandon 4,6532-8,7782 cfu/mL; dan air laut 4,6021-8,00 cfu/mL (Gambar 9).

Total vibrio selama pemeliharaan memperlihatkan populasi yang meningkat seiring dengan umur pemeliharan, baik dalam air tambak kedua perlakuan maupun dalam air tandon. Namun peningkatan yang paling ekstrem adalah dalam air laut pada akhir penelitian

Total vibrio dalam air tambak perlakuan $\mathrm{A}$ adalah 1.3979-2.8383 cfu/mL, relatif sama dengan perlakuan B 1.000-3.0607 cfu/mL dan air tandon 1,4771-3,1363 cfu/mL. Kisaran pada air laut dari 1,7782-4,0414 cfu/mL (Gambar 10)

\section{KESIMPULAN}

Dari hasil penelitian dapat disimpulkan bahwa pembesaran udang vaname teknologi intensif dengan menggunakan tokolan PL-27 dapat menghemat pakan dengan rasio konversi pakan lebih rendah: 1,096 $\pm 0,034$ dibanding dengan pembesaran menebar benur PL-12 yaitu: $1,257 \pm 0,048$. Sedangkan pertumbuhan mutlak, sintasan dan produksi relatif lebih tinggi pada pembesaran udang vaname menggunakan tokolan PL-27, namun berbeda tidak nyata dengan pembesaran dengan menebar benur PL-12.

\section{DAFTAR ACUAN}

Adiwijaya, D., Sapto, P.R., Sutikno, Sugeng, E., \& Subiyanto. 2003. Budidaya udang vaname (Litopenaeus vannamei) sistem tertutup yang ramah lingkungan. Departemen Kelautan dan Perikanan. Balai Besar Pengembangan Budidaya Air Payau Jepara, $29 \mathrm{hlm}$.

Anonim. 2003. Litopenaeus vannamei sebagai alternatif budidaya udang saat ini. PT Central Proteinaprima (Charoen Pokphand Group) Surabaya, $16 \mathrm{hlm}$.

Boyd, C.E. 1982. Water quality for pond fish culture. Elsevier Scientific Publishing Company, Amsterdam, 312 pp.

Boyd, C.E. \& Fast, A.W. 1992. Pond monitoring and management. Marine Shrimp Culture Principles and Practices. Elsevier Science Publishing Comp. Inc, New York, p. 497513

Clifford, H.C. 1994. Management of ponds stocked with Blue Shrimp Litopenaeus stylirostris. In Print, Proceedings of the $1^{\text {st }}$ Latin American Congress on Shrimp Culture, Panama City, Panama, p. 101-109.

Effendi, H. 2000. Telaah kualitas air bagi pengelolaan sumberdaya lingkungan perairan. Jurusan Manajemen Sumberdaya Perairan, FPIK-IPB. Bogor, $258 \mathrm{hlm}$. 
Mangampa, M. \& Mustafa, A. 1992. Penggunaan benur hasil pembantutan dan pengelolaan ransum pada budidaya udang windu, Penaeus monodon yang dibantut. J. Pen. Budidaya Pantai, 8(1): 37-40.

Mangampa, M. \& Hendrajat, E. 2008. Optimalisasi padat tebar udang vanamei (Litopenaeus vannamei) pada pentokolan sistim hapa. Prosiding Pusat Riset Perikanan Budidaya, $8 \mathrm{hlm}$.

Mangampa, M., Tahe, S., \& Suwoyo, H.S. 2009. Riset budidaya udang vanamei tradisional plus menggunakan benih tokolan dengan ukuran yang berbeda. Konferensi Akuakultur Indonesia 2009. MAl, Yogyakarta, 11 $\mathrm{hlm}$.

Mustafa, A. \& Mangampa, M. 1990. Usaha budidaya udang tambak menggunakan benur windu, Penaeus monodon yang berbeda lama pembantutannya. J. Penel. Budidaya Pantai, 6(2): 35-46.

Poernomo, A. 2004. Teknologi Probiotik Untuk Mengatasi Permasalahan Tambak udang dan Lingkungan Budidaya. Makalah disampaikan pada Simposium Nasional Pengembangan IImu dan Inovasi Teknologi dalam Budidaya. Semarang , 27-29 Januari. 2004, $24 \mathrm{hlm}$.

Suprapto. 2005. Petunjuk teknis budidaya udang vaname (Litopenaeus vannamei), CV Biotirta. Bandar Lampung, $25 \mathrm{hlm}$.

Tahe, S., Mangampa, M., \& Suwoyo, H.S. 2009. Seminar Forum Innovasi Teknologi Akuakultur. BRKP. Surabaya Juni 2009, $11 \mathrm{hlm}$. 